\title{
LANDSLIDE GEOHAZARD MONITORING, EARLY WARNING AND STABILIZATION CONTROL METHODS
}

\author{
ZBIGNIEW BEDNARCZYK \\ Institute of Opencast Mining, "Poltegor-Institute", Wrocław, \\ e-mail: zbigniew.bednarczyk@igo.wroc.pl.
}

\begin{abstract}
This paper is a presentation of landslide monitoring, early warning and remediation methods recommended for the Polish Carpathians. Instrumentation included standard and automatic on-line measurements with the real-time transfer of data to an Internet web server. The research was funded through EU Innovative Economy Programme and also by the SOPO Landslide Counteraction Project. The landslides investigated were characterized by relatively low rates of the displacements. These ranged from a few millimetres to several centimetres per year. Colluviums of clayey flysch deposits were of a soil-rock type with a very high plasticity and moisture content. The instrumentation consisted of 23 standard inclinometers set to depths of 5-21 m. The starting point of monitoring measurements was in January 2006. These were performed every 1-2 months over the period of 8 years. The measurements taken detected displacements from several millimetres to $40 \mathrm{~cm}$ set at a depth of 1-17 m. The modern, on-line monitoring and early warning system was installed in May 2010. The system is the first of its kind in Poland and only one of several such real-time systems in the world. The installation was working with the Local Road Authority in Gorlice. It contained three automatic field stations for investigation of landslide parameters to depths of $12-16 \mathrm{~m}$ and weather station. In-place tilt transducers and innovative 3D continuous inclinometer systems with sensors located every $0.5 \mathrm{~m}$ were used. It has the possibility of measuring a much greater range of movements compared to standard systems. The conventional and real-time data obtained provided a better recognition of the triggering parameters and the control of geohazard stabilizations. The monitoring methods chosen supplemented by numerical modelling could lead to more reliable forecasting of such landslides and could thus provide better control and landslide remediation possibilities also to stabilization works which prevent landslides.
\end{abstract}

Key words: monitoring systems, geotechnical engineering landslide investigations

\section{INTRODUCTION}

The mass movements in Polish Carpathians of approximately 35000 in number constitute over $90 \%$ in the country. Every year they are causing huge economic losses. It was especially seen during the flood in May-June 2010. Its activation caused damage to infrastructure, danger to persons and difficulties in the economy. In Polish Carpathians one landslide is reported for each one square kilometre of area and five kilometres of public road. The mass movements examined were activated mainly by intense precipitations. Flysch colluviums represented soilrock type of landslides (Cruden and Varnes [10], Hutchinson [13]). Flysch soils and rocks require the use of special research methods. Colluviums of this type were difficult to carry out in-situ or in laboratory tests. This was due to the fact that some of the soil test methods were not useful in the case of rocks. It should also be noted that landslides usually had few specific activation triggers in addition to slope inclination or geological stratification. The most commonly used method for landslide investigations in Poland is often only rotary drillings, sometimes merely by hand auger. Core drillings are very important, but also expensive and do not always provide all of the required data associated with the landslides, as, for example, the direction and depth of the movements. Therefore for precise landslide activity prediction geotechnical and geophysical monitoring could be particularly useful. Conventional methods require a number of field visits to obtain measurements and thus often are costly, especially when the travel costs are high. Automatic on-line systems are expensive, but more useful in high-risk areas (Agnelli et al. [1], Aylsworth et al. [2], Larsen [14], Senneset [16]). They allow for a quick and easy access to landslide data in real time and warn of hazards. In conjunction with numerical modelling, they enable the possibility of stabilization and control to be determined. Landslide monitoring networks in Poland 
are relatively rare, however access to monitoring data could prove design of effective remediation works. Geotechnical site investigations and stabilization works in Poland are often executed in a very short period of time. Usually this is over 4-5 months' period including implementation of the design of the stabilization project and obtaining the permit to start the construction works. This short time can cause difficulties because the recognition of all the necessary landslide parameters can take longer to conclude and thus this can result in the inefficient use of stabilization methods. Local administrations and road authorities often do not have precise monitoring data connected with the activity of these natural hazards, however, in recent years monitoring measurements have been implemented more frequently. The author of this paper had the opportunity to perform monitoring measurements at selected Carpathian locations for a period of more than eight years. The landslide monitoring network installation was carried out whithin the framework of the SOPO Landslide Counteraction Project. An on-line early-warning system of landslide hazards was implemented whithin the framework of the EU Innovative Economy Program. Other instrumentation was done within the projects for the Polish Oil and Gas Company, local administration and partly fi- nanced by Poltegor-Institute. The new on-line system is the first of its kind in Poland and has been in operation since May 2010. The monitoring network was designed for the protection of roads and infrastructure, to determine ways of preventing landslides, to recognize the main triggering factors and to warn of possible hazards. The results of the work presented in this paper have been provided to local administrations and road authorities for the design of remediation works and the warning of the risks.

\section{LANDSLIDE LOCALIZATON}

The geohazards investigated were located in southern and southeastern Poland. The study was conducted in 23 areas where landslides seriously endanger public roads and infrastructure. A monitoring network was installed close to the public roads near the town of Gorlice. Standard monitoring measurements were carried out from January 2006 till now every 1-2 months. Real-time monitoring started in May 2010, just prior to a record period of landslide activity during the flooding in southern Poland. The location of landslides and monitoring of network elements near the town of Gorlice is shown in Fig. 1.



Fig. 1. Localization of landslide monitoring network in Gorlice region 


\section{ENGINEERING GEOLOGY CONDITIONS}

Landslides selected for the research mainly occurred in marine Eocene flysch deposits, consisting of many thin layers of claystones and sandstones. These were folded, uplifted and cut by faults, which occurred during the Alpine orogenesis. Climate change in the Holocene era led to the creation of thick weathering zones and the activation of a huge number of reactivated landslides (Raczkowski and Mrozek [15]). These movement triggers were of geological stratification, steep slope inclination, the erosion processes in rivers and valleys, intense rainfalls and the melting of snow cover (Gil and Długosz [12]). Displacements depend on relatively steep slope inclinations in conjunction with low strength parameters of heavily saturated clayey layers. These conditions resulted in mass movements that were reactivated several times during groundwater level depth and pore pressure changes after intense rainfalls. Landslides were formed in clayey flysch sediments with high moisture content and thus plasticity. The volume of landslides investigated ranged from 0.4 to $2.2 \mathrm{mln} \mathrm{\textrm {m } ^ { 3 }}$. Colluviums which were a heterogeneous mixture of laminated shales and weathered sandstone rubble were the main constituents. Saturated clayey schist with mechanically as a weak cohesive soil had unfavourable strength parameters. Sandstones frequently occurred in thin layers with varying degrees of diagenesis within the clayey soils. This allowed for the infiltration of rainwater, which also predestined fractures and faults occurring. Displacements typically occurring on slopes were characterized by shallow groundwater level $(0.5-1.5 \mathrm{~m})$ with a slope inclination of $15^{\circ}-35^{\circ}$. Colluvium depths were variable and ranged from a few to over $18 \mathrm{~m}$. Intense precipitation and the spring snowmelt resulted in a variation of pore water pressure and the increasing range of movements observed. This problem intensified in May-June 2010, after very heavy rainfalls. Several landslides were then activated, causing serious damage to buildings, roads and other infrastructure, as well as a negative impact on the environment.

\section{SITE INVESTIGATIONS}

Engineering geology site reports were prepared for 23 landslides from 2005 to 2009 . As a part of this work, subsequent geotechnical engineering studies and geophysical investigations were performed. Over- all over $800 \mathrm{~m}$ of core boreholes were drilled and recorded. A drilling rig with a dual core diamond bit, with a diameter of $132 \mathrm{~mm}$, was implemented for this purpose. Boreholes were drilled to a depth of 9-30 m. Careful coring provided a high yield of the core samples and provided accurate profiles. These drilling works also included undisturbed sampling using the Shelby cylinder. In order to better understand the geological structure between the boreholes more than $30 \mathrm{~km}$ of RAMAC-GPR profiling was completed. Boreholes were carefully scaled for geophysical results. For landslide mapping GPS-RTK measurements were implemented, which allowed actual landslide maps with horizontal and vertical accuracy to $1 \mathrm{~cm}$ in post-processing to be obtained. GPR geophysical surveys with $100 \mathrm{MHz}$ unshielded antennas provided recognition of the internal structures of colluviums and led to the identification of layers and bedrock depths. An update of the actual landslide terrain morphology was very important due to the lack of current landslide mapping in remote areas. For this reason standard geodesy surveying was supplemented by GPS-RTK measurements, which was an effective method for landslide mapping. Monitoring measurements in the new network were carried out over a period of eight years. They had to be partly financed by the author in the absence of any available other sources. The inclinometer and piezometer surveys provided information on mass movement dynamic and depths. In 2010, over the public Szymbark-Szalowa road a new on-line early warning was installed. The results obtained from monitoring 23 landslides were used for numerical modelling and landslide stabilization.

\section{LABORATORY TESTS}

Geotechnical laboratory tests included index test - grain size, natural moisture content, plastic and liquid limit, bulk density, grain-size density, and content of organic/bituminous material. Other types of tests were direct shear test, IL oedometer, CIU and CID triaxial tests. The results of grain size tests detected that colluviums represented silty clays, loams, gravely loams, claystones and sandstones (bedrock). The soil samples investigated had a very high natural moisture content $18-37 \%$, varying strength $0.1-0.8,6.5-10 \mathrm{kPa}$ consistency, with an angle of internal friction of $11-15^{\circ}$ and very high compressibility. The highest values of moisture content and plasticity were observed in samples taken near the slip surface to depths of approxi- 


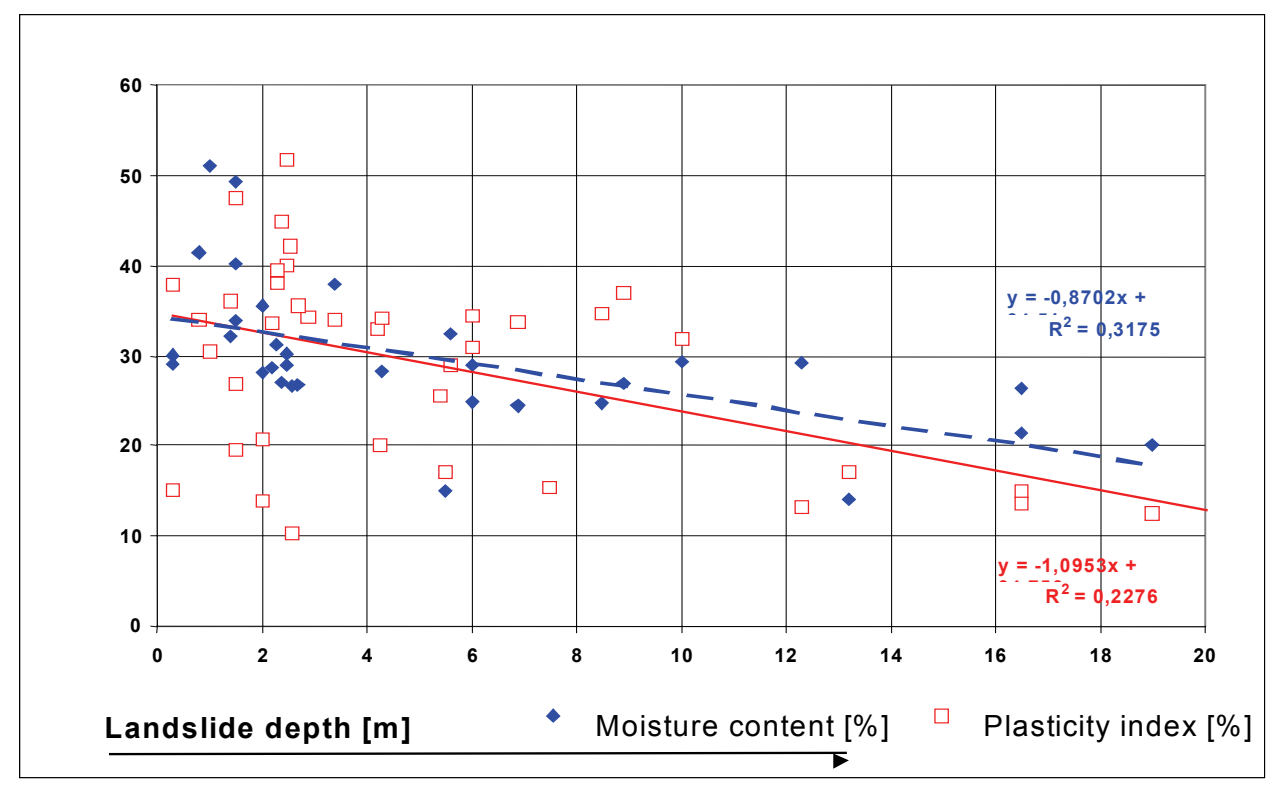

Fig. 2. Results of index laboratory tests

mately 2-10 m (Fig. 2). The depths of the slip surface were in a good correlation with maximum values of moisture content and plasticity index.

\section{NATURAL HAZARD PREDITION AND MONITORING}

Monitoring measurements are essential for landslide hazard estimation. They could also significantly improve the effectiveness of road area stabilization. However, a fully effective method for predicting landslide hazard that could determine its exact time and eliminate threats, has not been developed yet. This is due to a very complex genesis of these processes. Typically, in addition to the main activation factors, there are several different internal and external triggers. The method of layers deposition, lithology, slope inclination, occurrence of faults and folds, the mechanical parameters of soils or rocks, precipitation values, seepage processes, weathering and erosion processes as well as a number of unlisted factors may variously affect the development of landslides. Some very large and active mass movements cannot be stabilized. Other location of high importance for the economy had to be previously carefully recognized. This was especially important because of usually very high cost of stabilization. The monitoring network presented was designed in order to determine the parameters of Carpathian landslides investigated (Bednarczyk 2008-2013). The instrumentation contained more than $400 \mathrm{~m} \mathrm{ABS}$ inclinometer tubes fitted with special joints to measure the subsidence at a depth of slip surface. Groundwater level depth and pore pressure measurements were performed to estimate the effective stress in the colluviums. Conventional monitoring methods were used for ground movements and piezometer monitoring. These included standpipe piezometers, pneumatic and automatic piezoelectric pore pressure transducers. The network included 23 monitoring locations. Every point consisted of an inclinometer and a piezometer (standpipe or pore pressure transducer). The monitoring programme included readings taken every 30-45 days over a period of eight years. Verification of accurate results enables recognition of representative individual displacements, their directions and depths in profiles studied (Figs. 3, 4). The results of analysis of the relationship between the size of displacements observed and the average monthly rainfall $(\mathrm{cm})$, groundwater depth (h), groundwater temperature (C) and pore pressures measured by a piezoelectric $\left(u_{1}\right)$ and pneumatic transducers $(u)$ from the landslide in Szymbark are shown in Fig. 4. This comparison indicates that the greatest displacement occurred when the pore pressure decreased after reaching high values $(60-65 \mathrm{kPa})$. The largest incremental displacement occurred in May $2006(11.2 \mathrm{~mm})$ in March 2007 (5.3 mm) during the stabilization in $2009(53.9 \mathrm{~mm})$ and May-June 2010 $(100 \mathrm{~mm})$. The cumulative displacements observed during the monitoring period, depending on landslide activity ranged from a few to over $400 \mathrm{~mm}$ (after damage of inclinometer casings). 

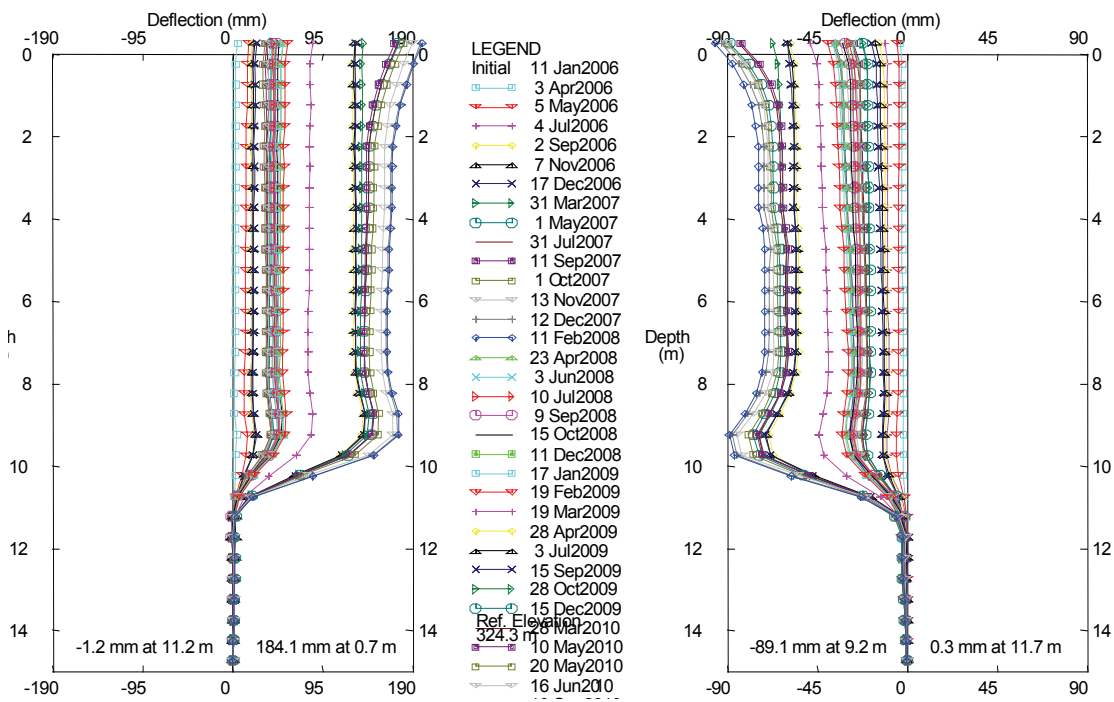

Fig. 3. Cumulative displacements - Szymbark



Fig. 4. Monitoring parameters plotted - Szymbark landslide
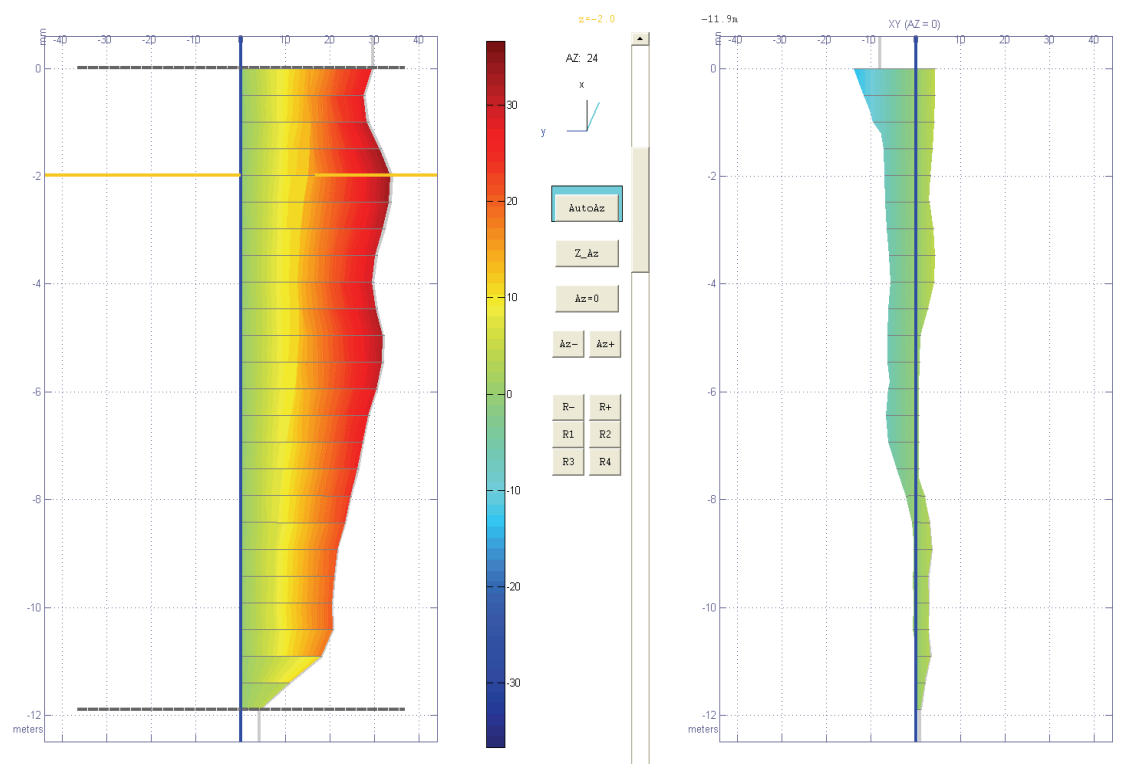

Fig. 5. Cumulative on-line displacements [mm] 


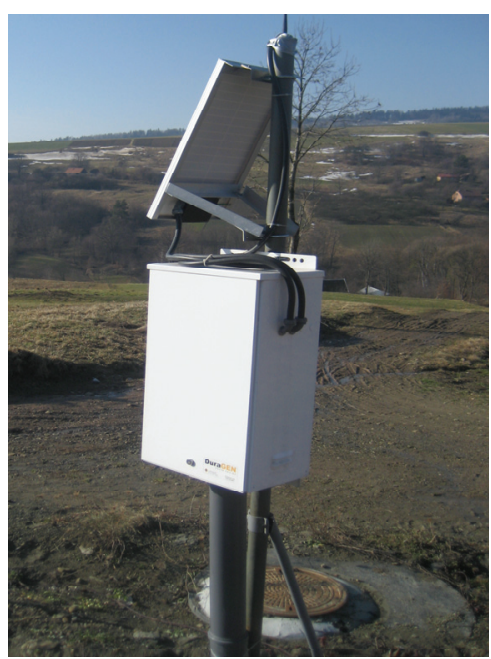

Fig. 6. Continuous 3D inclinometer on-line station

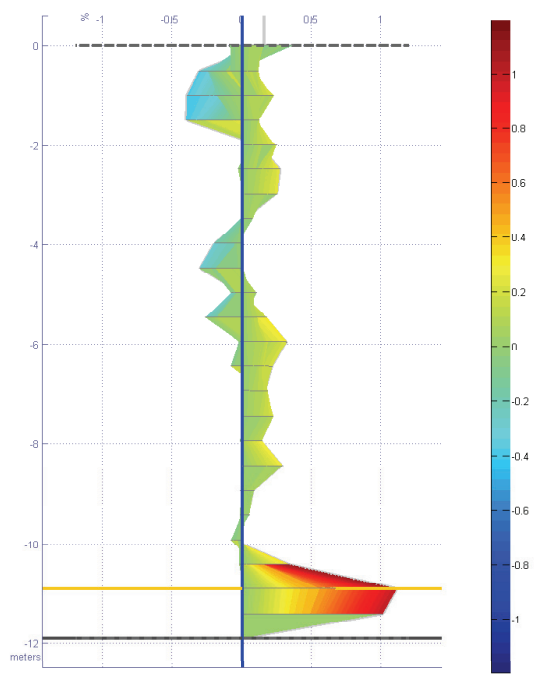

The inclinometer casing at Szymbark landslide was damaged by displacements of $150-180 \mathrm{~mm}$ in size and at a depth of $11 \mathrm{~m}$ (Fig. 3). The highest monthly displacements of $12 \mathrm{~mm}$ were observed during May-June 2006 at Sekowa landslide. They occurred after record monthly rainfall $230 \mathrm{~mm}$, which contributed to high pore pressures values of $45-50 \mathrm{kPa}$. Movements were usually activated after a period when the pore pressure on the slip surface reached $50-65 \mathrm{kPa}$ (Fig. 4). The size of displacements has a better correlation with the values of pore pressure than the depth of the groundwater level. The monitoring data obtained was used for numerical slope stability analyzis. They provided the recognition of stabilization possibilities. At the end of May 2010 the first real-time monitoring system in Poland was

Fig. 7. Shear strain plot on-line

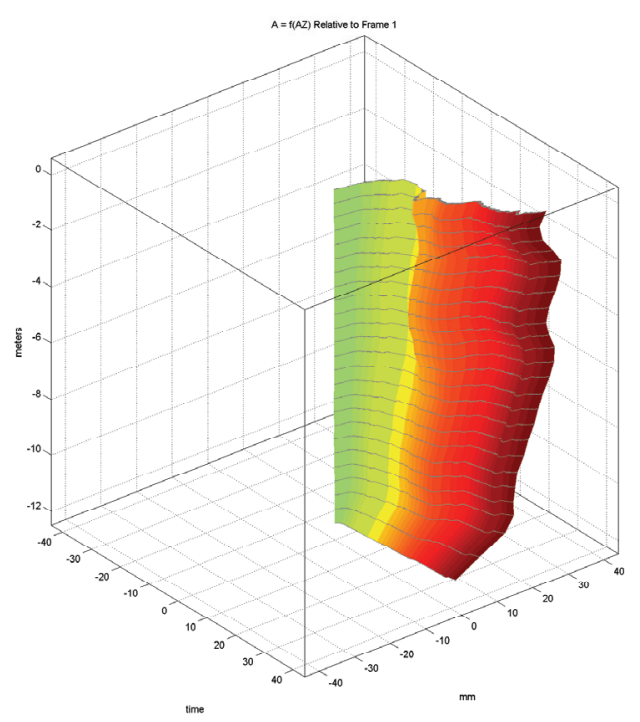

Fig. 8. Displacements on-line - 3D model installed in the area of landslides at Szymbark. The time of installation coincided with record high rainfall. The reading taken from the automatic weather station reached $100 \mathrm{~mm} / \mathrm{m}^{2}$ on June 2. Four field measuring stations were built over a public road Szymbark-Szalowa (Figs. 5-8). Innovative continuous inclinometer 3D systems consisting of tilt sensors every $0.5 \mathrm{~m}$ to depths of $12 \mathrm{~m}$ and $16 \mathrm{~m}$ were set up. They included a total of 66 tilt sensors which allowed much greater range of displacements to be measured compared with the standard inclinometers. This type of system could in some cases stand displacements of up to $3 \mathrm{~m}$. Another automatic on-line "in-place" inclinometer system with 3 uniaxial sensors had a length of $14 \mathrm{~m}$. Ground movement measuring devices were supplemented by three automatic pore pressure and groundwater level transducers and an on-line weather station. During the first 23 months 
of operation of the system maximum displacement reached 20-32 $\mathrm{mm}$. The total deformation was calculated from the equation: $D=\sqrt{\left(x^{2}+y^{2}\right)}$ (Dunnicliff [11]). Registered on-line displacement reached $22-34 \mathrm{~mm}$ to the depth of $12-15 \mathrm{~m}$. Real-time measurements will be conducted till the end of 2014 .

\section{NUMERICAL MODELING}

The stability of the slopes investigated, besides the internal geological factors, soil strength parameters and slope inclination, was dependent on external factors. The occurrence of intensive rainfall, pore pres- sure and groundwater level variations and erosion in river valleys were the main cause of mass movement triggers. These factors increased the value of shear stresses and effective stresses, which adversely affected the strength parameters of the slopes. In some cases, displacements were activated by additional external factors, such as the undercutting of a head landslide zone during road construction and the exclusion of agricultural land. Most of the flysch landslides investigated were characterized by complex internal structures reactivated many times. The slope stability analysis carried out made it possible to introduce these essential slope elements. Calculations were based on LEM limit equilibrium Janbu, Bishop and Morgenstern-Price methods for analyzing the most probable

Slope stability analysis, Szymbark Lands lide no 5 , Janbu method, after stabilization $F_{\S}=1.37$

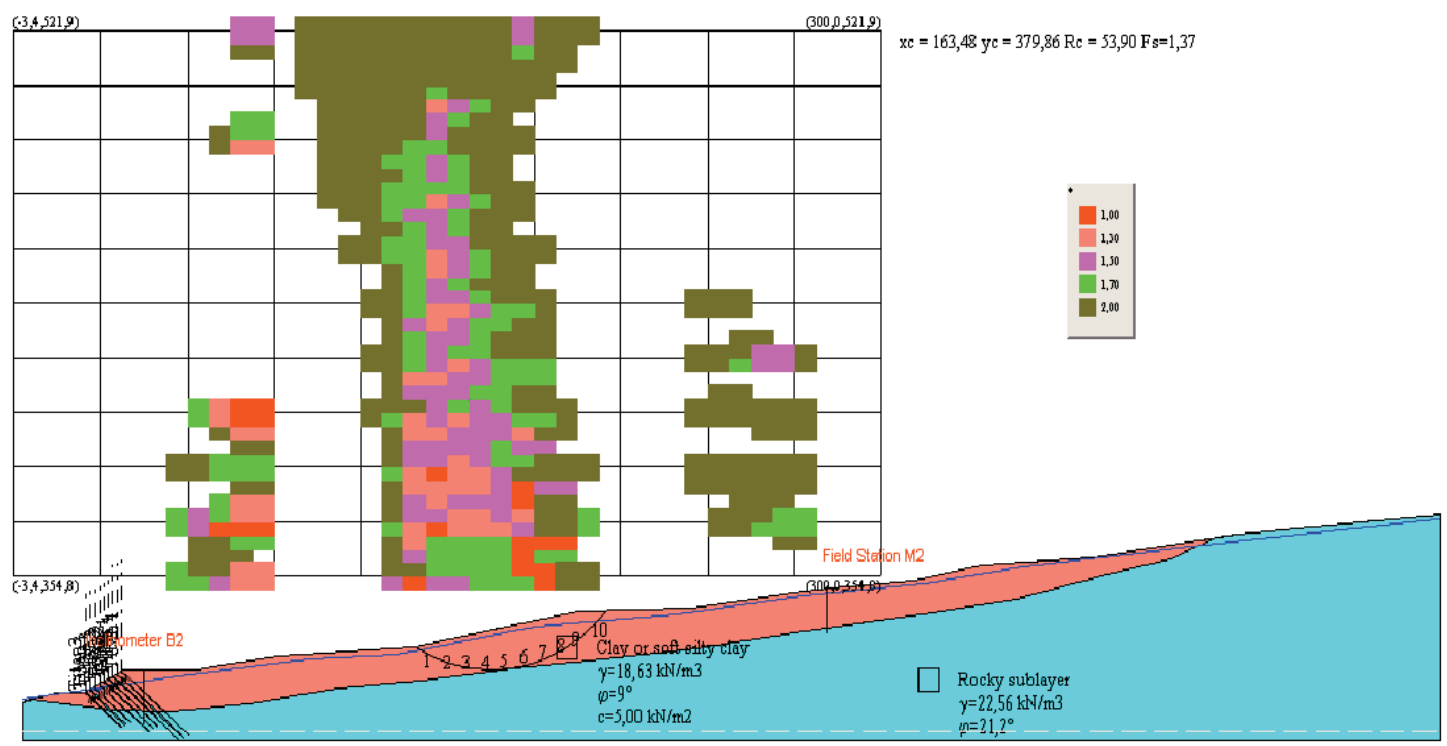

Fig. 9. FEM slope stability - Sekowa landslide

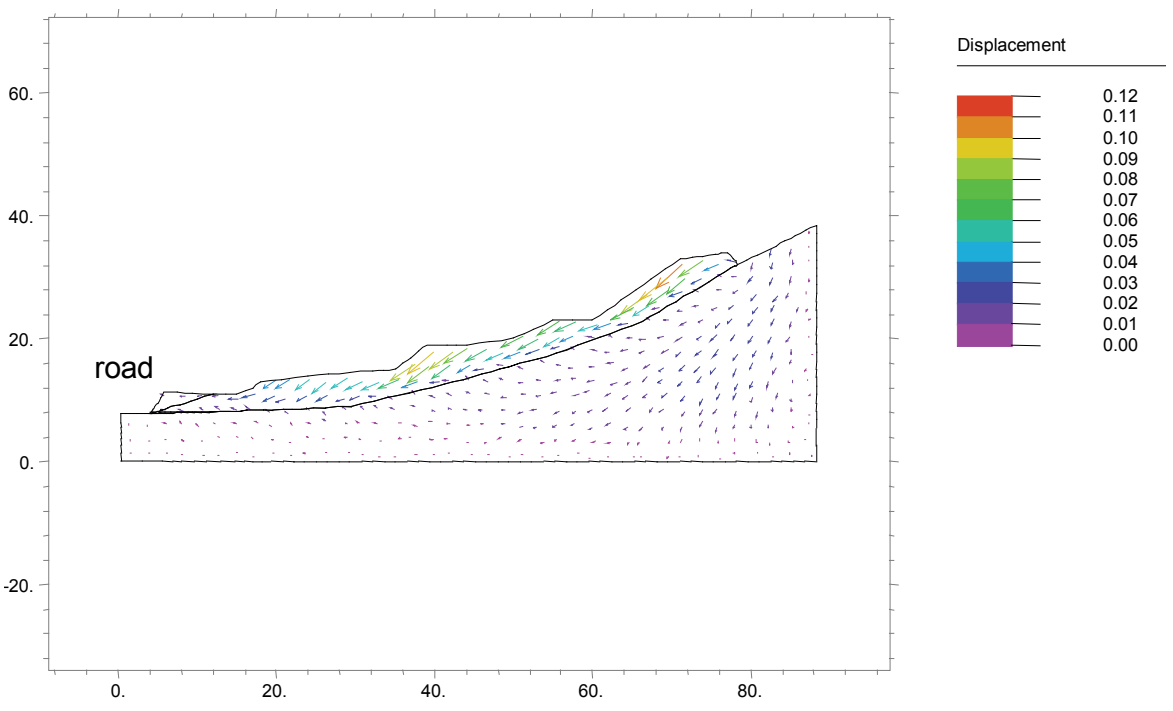

Fig. 10. LEM slope stability analysis - Szymbark landslide 
circular slip surfaces (Fig. 10). The stabilization methods proposed had been tested using conventional limit equilibrium methods LEM, with calculations based on the relative slope stability factor. However for the landslide in Sekowa, the value of $F_{S}$, calculated were slightly above $F_{S}=1.13$ before stabilizing and $F_{S}=$ 1.58 after it. After the remediation work the most probable slip surfaces were located always away from public roads. The expected displacements were also calculated using Finite Elements FEM methods taking the results of monitoring in the definition of the boundary conditions into account. Modelling detected that the total displacement expected at landslide in Sekowa could reach up to $12 \mathrm{~cm}$ without stabilization works (Fig. 9). The plot of the final FEM mesh without stabilization works indicated that the landslide was active and dangerous to the public road.

\section{DESIGN AND CONTROL OF REMEDIATION WORKS}

The implementation of effective remediation work required landslide site investigations. Selected monitoring methods and measurements should be carried out over a sufficiently long period of time (a minimum period of 12 months). Research showed that full stabilization of some of the landslides studied could be very difficult or even impossible for economic reasons. This was due to the size of the landslides as well as the depths and the scope of the movements observed. Data obtained from geotechnical site investigations and monitoring were necessary for the im-

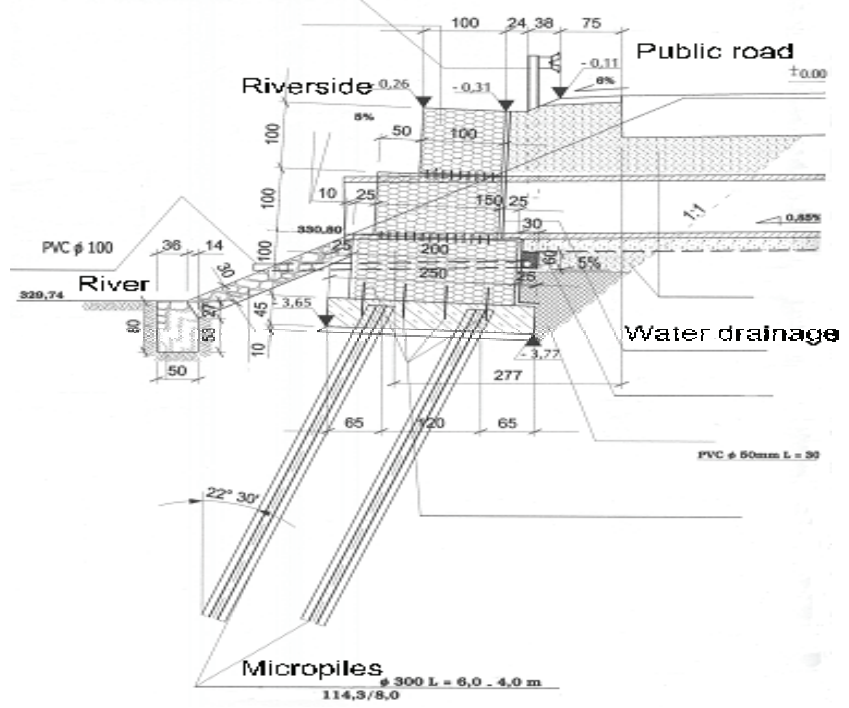

Fig. 11. Retaining wall along the river - Sekowa landslide

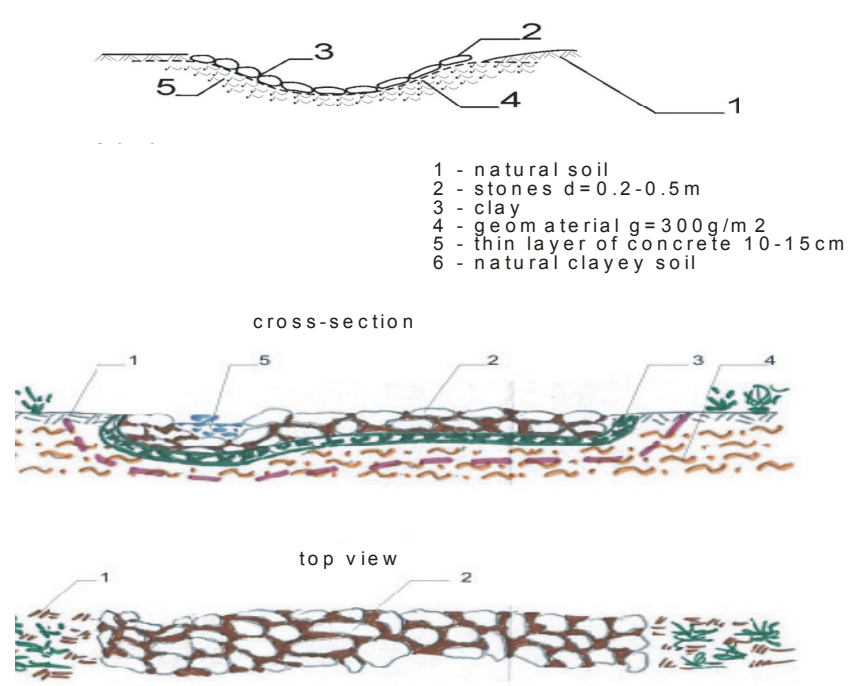

Fig. 12. Surface drainage - Sekowa landslide

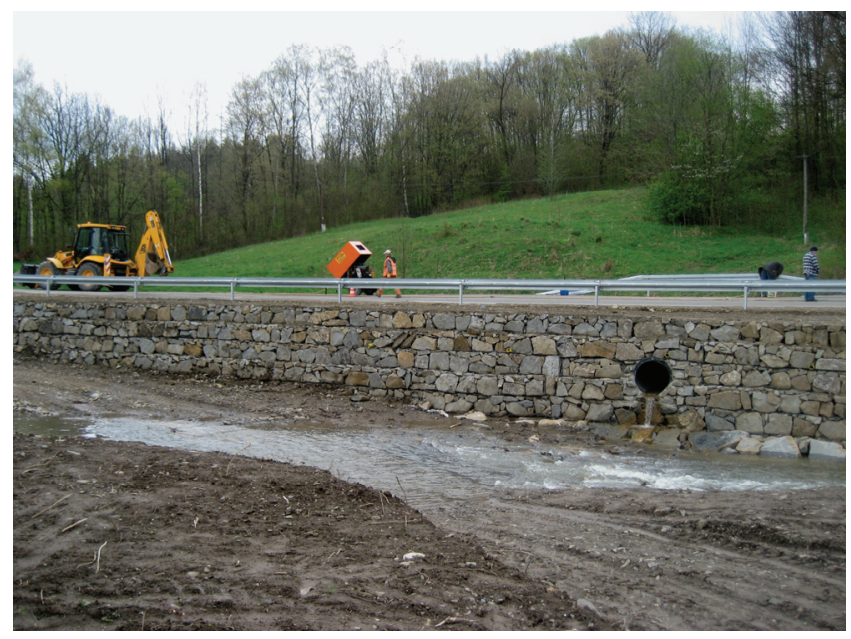

Fig. 13. Stabilization works at Sekowa landslide

plementation of effective stabilization work. These included landslide depth, size, directions of displacements, the strength parameters of colluviums as well as bedrock and groundwater conditions. Slope protection contributed to the decrease of risk to public roads and to the improvement of stability conditions. Monitoring measurements allowed the factors which activate the landslide processes to be interpreted. Various methods of stabilization were used. For example, a gabion retaining wall founded on 300 micropiles to a depth of $6 \mathrm{~m}$ at a distance of $200 \mathrm{~m}$ along the river was built for the Sekowa landslide (Figs. 11, 13). The central part of this landslide retaining wall constructed along the length of over $30 \mathrm{~m}$ was set on 60 micropiles at a depth of $11 \mathrm{~m}$ in three rows, $300 \mathrm{~mm}$ in diameter. The first row was tilted at an angle $11^{\circ}$, the two others were made vertically. The upper part of the micropiles was connected by a special supporting construction of reinforced concrete. The surface drain- 
Table 1

Control of stabilization works

\begin{tabular}{|l|c|c|c|c|c|c|}
\hline Landslide & $\begin{array}{c}\text { Volume } \\
{\left[\mathrm{mln} \mathrm{m}^{3}\right]}\end{array}$ & $\begin{array}{c}\text { Depth } \\
{[\mathrm{m}]}\end{array}$ & $\begin{array}{c}\text { Stabilization } \\
\text { date }\end{array}$ & $\begin{array}{c}\text { Displacements } \\
\text { before stabilization } \\
{[\mathrm{mm}]}\end{array}$ & $\begin{array}{c}\text { Displacements } \\
\text { during stabilization } \\
{[\mathrm{mm}]}\end{array}$ & $\begin{array}{c}\text { Displacements } \\
\text { after stabilization } \\
{[\mathrm{mm}]}\end{array}$ \\
\hline Sekowa & 0.4 & $2.7-5.1$ & 2007 & 26 & 61 & 5 \\
\hline Szymbark & 2.2 & $1.3-15$ & 2009 & 138 & 19 & $13-30$ \\
\hline
\end{tabular}

age system, which has a total length of $300 \mathrm{~m}$, took the rainwater away from the landslide area into the river through a new culvert under the road (Figs. 12, 13). However during stabilization, after intense rainfalls mass movement activation of up to $60 \mathrm{~mm}$ was observed. After remediation works, the size of the observed movement will hopefully be reduced to $+/-5 \mathrm{~mm}$ within a five years' period. The values of the groundwater pore pressure which were equal to $45 \mathrm{kPa}$ before the stabilization works reduced to approximately $30 \mathrm{kPa}$. The depth of the groundwater level was reduced from $1.3-1.8 \mathrm{~m}$ to $2-2.2 \mathrm{~m}$. The conclusions from the monitoring measurements and the control of stabilization are shown in Table 1.

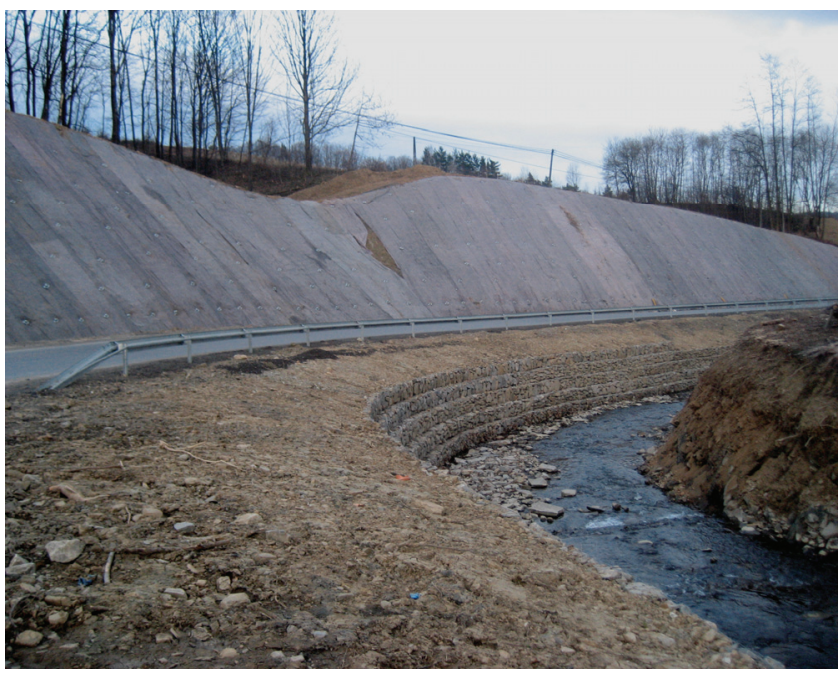

Fig. 14. Landslide in Szymbark after partial stabilization

For landslide in Szymbark, several concepts of stabilization or temporary protection were considered due to the large size of the area and the risks posed (Fig. 14). The remediation implemented allowed for the partial stabilization of the landslide head. For this purpose the anchors of up to $20 \mathrm{~m}$ in length were installed in the bedrock. Anchors and high tensile Geobrugg wire mesh supported the landslide head part. Partial stabilization works also included a gabion retaining wall along the Bystrzanka River. The surface and internal drainage system (horizontal drains and drainage wells), and two new culverts under public road had to protect slopes from the influence of rainfall. After securing the road, the groundwater pore pressure decreased (48-30 $\mathrm{kPa}$ in Sekowa and 50-15 $\mathrm{kPa}$ in Szymbark). However, in Szymbark despite the partial stabilization, the displacement of the size of $13-20 \mathrm{~mm}$ occurred. They intensified especially after record rainfalls in May-June 2010, which caused flooding in neighbouring regions. The methods used for the stabilization reduced the risk and secured the threatened sections of public roads which was confirmed by monitoring measurements. The values of observed movements ranged from 26 to $138 \mathrm{~mm}$. In some cases, they increased to more than $60 \mathrm{~mm}$ during stabilization works, which was often caused by the fact that these were carried out at the end of the year in adverse weather conditions. After remediation work the displacement usually had been typically reduced to $+/-$ a few $\mathrm{mm}$. The landslide in Szymbark with partial stabilization recorded displacement of $10 \mathrm{~mm}$ in the first year. However, after record rainfall movements rose in some places to $18 \mathrm{~mm}$, which was detected in real time by an automatic early warning system (Figs. 5-8).

\section{CONCLUSIONS}

The paper presents research methods used for the monitoring of landslide natural hazard and the design and control of stabilization works. The results of ground movement and groundwater conditions were analyzed at 23 monitoring points in the Polish Carpathians. Results obtained have been used for the preparation of nineteen geological-engineering site documentation and six landslide stabilization design projects. Monitoring measurements were performed over a period of more than eight years beginning from January 2006 and carried every 1-2 months to October 2013. Modelling and monitoring methods proved determining the degree of landslide activity, the design of stabilization works and their control. The main activating factors of mass movement were connected with intensive precipitation and changes in pore 




Fig. 15. Comparison of the monitoring results in 23 landslide locations

pressure in the range of $15-65 \mathrm{kPa}$. A comparison of monitoring results is shown in Fig. 15. The displacements were observed to a depth of $11.5-16 \mathrm{~m}$ and reached a size of $22-34 \mathrm{~mm}$ while pore pressure values of 48-65 kPa were also noted. The results of the monitoring measurements were included in the analysis of stability by LEM and FEM methods for slopes before and after stabilization works. In May 2010 after record high precipitation, displacement increased to more than $11 \mathrm{~cm}$ within 1 day in some areas. Stabilization methods were fully effective on the landslide in Sekowa. In the four-year time period after stabilization the displacement observed reached only a few millimetres. At the large and dangerous landslide in Szymbark a partial remediation limited the scope of movements. However, partial stabilization works could not be fully effective after extremely high rainfall. It was particularly noticeable in May 2010. The results of the research showed that large and active flysch landslides were difficult to stabilize. Remediation projects should therefore be carried out according to local geotechnical conditions in a reasonably long period of monitoring time (minimum 12 months). This is particularly important because of the huge cost of remediation works. Implementation with various site-specific investigations and monitoring methods and models can result in a more reliable diagnosis of possible options of stabilization and provide information about potential hazards. The implementation of new techniques for real- time monitoring allowed a continuous observation of landslide behaviour and geohazard warning. The new on-line early warning system which is the first of its kind in Poland has been tested in Beskid Niski Mts. over a public road. The research presented provided landslide data and defined the threats to public roads and infrastructure. It was delivered to local administrations and road authorities. It should be noted that due to the nature of processes observed their specific identification was usually difficult. For this reason, investigation type and instrumentation must be carefully planned and carried out long before stabilization works proceed.

\section{REFERENCES}

[1] Agneli M.G., Pasuto A., Silvano S., A critical review of landslide monitoring experiences, Engineering Geology, 2000, 55, 133-147

[2] Aylsworth J.M., Duk-Rodkin A., Robertson T., Traynor J.A., Landslides in the physical environment on Mackenzie Valley, Geological Survey of Canada Bull., 2000, No. 547, 41-48.

[3] BednARczyK Z., An on-line landslide monitoring system in flysch Carpathians. Proc. of EUROCK 2013 International Symposium Rock Mechanics for Resources, Energy and Environment, International Society for Rock Mechanics ISRM, Polish Society for Rock Mechanics, Institute of Geotechnics and Hydrotechnics of Wrocław University of Technology, edited by Kwaśniewski M, Łydżba D, CRC Press/Taylor \& Francis Group Balkema, 2013, 604-611. 
[4] Bednarczyk Z., Real-Time Landslide Monitoring System in Polish Carpathians, Landslide Science and Practice, Vol. 2, Early Warning, Instrumentation and Monitoring, Springer, 2013, 3-15.

[5] Bednarczyk Z., Pierwszy w Polsce system wczesnego ostrzegania o zagrożeniu osuwiskowym $w$ czasie rzeczywistym na podstawie wybranych lokalizacji w Beskidach, Biuletyn Państ. Inst. Geologicznego, Nr 445 (1), Współczesne Problemy Geologii Inżynierskiej w Polsce, 2011, 1-7.

[6] BednARCZyK Z., Soil-Structure Interaction on Three Stabilized Flysch Landslides in Polish Carpathians, The Proc. of the First Intern. Conf. on Advances in Multiscale Mechanics AIMM'10, Korea Advanced Institute of Science \& Technology KAIST, U.S. Air Force Office of Scientific Research, S. Korea, Techno-Press, 2010, 1389-1397.

[7] BednarczyK Z., SzyNKIEWICZ A., Ground Penetrating Radar (GPR) Scanning In Geological And Geotechnical Recognition of Mountain Site, 22 SAGEEP Symposium, Fort Worth, Texas USA, EEGS, US Army Research Office, 2009, 731-738.

[8] BEDNARCZYK Z., Landslide geotechnical monitoring network for mitigation measures in chosen locations inside the SOPO Landslide Counteraction Framework Project Carpathian Mountains, Poland, The First World Landslide Forum, Tokyo, International Consortium of Landslides ICL, UN, 2008, 71-75.

[9] BEDNARCZYK Z., Flysch landslides geotechnical monitoring in Beskidy, The Carpathian Mountains Poland, The 3rd International Conference on Site Characterization, ISSMGE, Taipei, Taiwan, edited by An-Bin Huang \& Paul Mayne, Taylor \& Francis, London, 2008, 269-274.
[10] Cruden D.M., Varnes D.J., Landslides Types and Processes, [in:] A.K. Turner, R.L. Schuster (eds.), Landslides Investigation and Mitigation, Washington D.C., National Academy Press, Transportation Research Board Special Report, 1996, 247, 36-75.

[11] DunNICLIFF J., Geotechnical Instrumentation for Monitoring Field Perform, J. Wiley \& Sons, 1993.

[12] GIL E., DLugosz M., Threshold values of rainfalls triggering selected deep-seated landslides in Polish Flysch Carpathians, Stud. Geom. Carpatho-Balc., 2006, 40 Vol. XL, 21-43.

[13] Hutchinson J.N., General Report Morphological and geotechnical parameters of landslides in relation to geology and hydrogeology, Proceedings Fifth International Symposium on Landslides (ED; Bonnard C.) Balkema, Rotterdam, 1988, 3-35.

[14] LARSEN J.O., Same aspects of physical weather related slope processes, Thesis submitted to the faculty of Engineering Science and Technology in partial fulfilment of the requirements for the degree of Doctor of Engineering. NTNU Norway, 2002, 1-70.

[15] RaczKowski W., MrozeK T., Activating of landsliding in the Polish Flysch Carpathians by he end of 20th century, Studia Geom. Carpatho-Balcanica, 2002, 36, 91-111.

[16] Senneset K., Natural and Man-Hade Hazards: Landslides, Stability analysis, control, case histories, General Report Norges Teknisk-Naturvitenskapelige Universitet, Bull. 34, Trondheim, 1998, 1-14. 